\title{
The New Experiential Impacts Linked to the Application of Knowledge Management in Businesses
}

Mintah Clement, Chen Huaicheo, Aloo Felicia, Adu Sarfo Philip, Sam Hayford Isaac, Ofori Elvis Kwame, Nwokebuife Onyinyechi Juliana

To Link this Article: http://dx.doi.org/10.6007/IJARBSS/v11-i12/11269 DOI:10.6007/IJARBSS/v11-i12/11269

Received: 17 October 2021, Revised: 22 November 2021, Accepted: 02 December 2021

Published Online: 21 December 2021

In-Text Citation: (Clement et al., 2021)

To Cite this Article: Clement, M., Huaicheo, C., Aloo Felicia, A. S. P., Isaac, S. H., Kwame, O. E., \& Juliana, N. O. (2021). The New Experiential Impacts Linked to the Application of Knowledge Management in Businesses. International Journal of Academic Research in Business and Social Sciences, 11(12), 1540-1556.

Copyright: () 2021 The Author(s)

Published by Human Resource Management Academic Research Society (www.hrmars.com) This article is published under the Creative Commons Attribution (CC BY 4.0) license. Anyone may reproduce, distribute, translate and create derivative works of this article (for both commercial and non0-commercial purposes), subject to full attribution to the original publication and authors. The full terms of this license may be seen at: http://creativecommons.org/licences/by/4.0/legalcode

Vol. 11, No. 12, 2021, Pg. 1540 - 1556

Full Terms \& Conditions of access and use can be found at http://hrmars.com/index.php/pages/detail/publication-ethics 


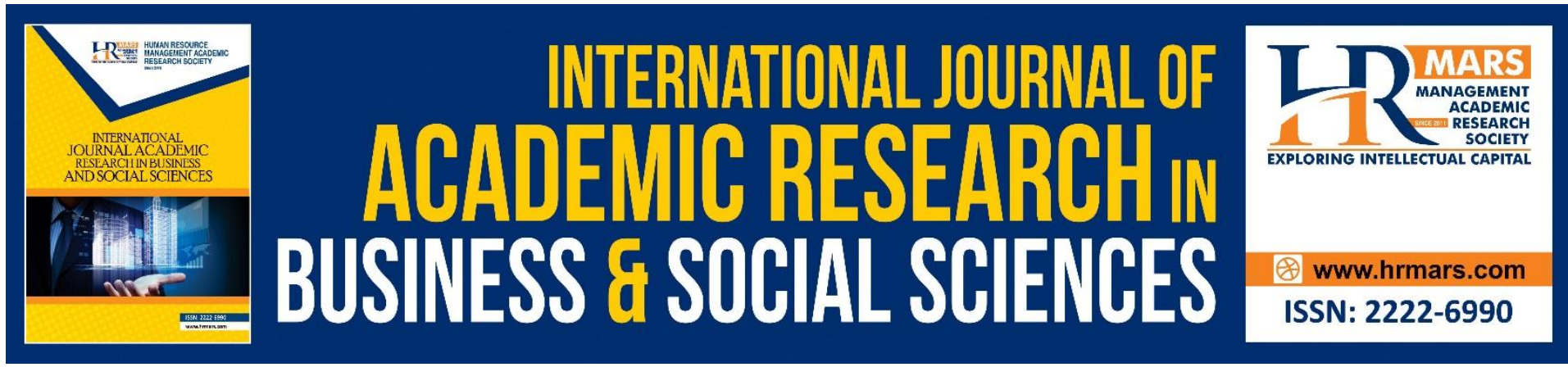

\title{
The New Experiential Impacts Linked to the Application of Knowledge Management in Businesses
}

\section{Mintah Clement, Chen Huaicheo, Aloo Felicia, Adu Sarfo Philip, Sam Hayford Isaac, Ofori Elvis Kwame, Nwokebuife Onyinyechi Juliana}

College of Economics and Management, Taiyuan University of Technology, Taiyuan, 030024, China.

Email: yawmintahclement@gmail.com,chenhch04@126.com, alooafelicia@gmail.com, adusarfophilip@yahoo.com, samhayford92@gmail.com, oforikwamee@gmail.com,

7julianagift77@gmail.com

\begin{abstract}
In recent times, the emergence of knowledge and its application is fundamental to success and failure, for individuals, societies, business and corporate governance. Therefore, there is the neeed to tap up knowledge, disseminate and use for gaining a competitive advantage, despite the existing difficulties. Hence, having a pre-requisite knowledge on staff recruitment quality, employee's behavior to change management, inadvertent tacit knowledge, and knowledge update programs and their application will help determine the success of KM implementation in companies. In the process of KM implementation, some of the constraining factors are more general and have consequences on the knowledge management implementation process. However, enhancing and sustaining a competitive advantage and developing further innovative business strategies through the knowledge management implementation process is a means to grow companies, and achieve economic prosperity. This study examines the barriers to knowledge management implementation (KMI) and how they impact the implementation process in ten (10) companies in Ghana. The investigation was conducted using a survey design, which used valid sample adequacy of 295 respondents. Multiple linear regression model and ANOVA tests were applied. Our findings discovered a linked and aggregated impacts on the in dependent variable. The study revealed that staff recruitment quality and knowledge update programs have direct and positive effect on the KM implementation process (see figure 1). However, individual's inadvertent tacit knowledge and individual's resistance to change management were not statistically significant on the knowledge implementation process (see figure 1). Hence, companies must see staff recruitment quality, resistance to change management, inadvertent tacit knowledge, and knowledge update programs as variables with either positive or negative impact on KM implementation in businesses. Findings add to existing information in the fields of business and industrial management. We conclude that
\end{abstract}


resistance to change management and tacit knowledge of individual employees are hindrance to knowledge management implementation process which will consequently affect business growth. Therefore, we advance knowledge for business and industrial management for policy consideration.

Keywords: Knowledge Management Implementation, Impediments, Enablers, Ghana.

\section{Introduction}

Knowledge management is the most important aspect of today's business performance. Achieving this performance goal in a company has its own set of benefits and drawbacks. The researcher spent considerable time in this work assessing knowledge management implementation issues confronting purposively sampled firms. The goal of the research is to better understand the interactions between knowledge management implementation and its enablers and impediments on the long-term viability of firms in their quest of implementing. The (OECD, 2005) have identified and echoed the broad patterns in the rising informationbased economy, which provide the foundation for strategic planning in businesses and organizations. This entailed addressing some fundamental questions, including: Can we identify the general tendencies in the information-based market that characterize the knowledge environment in which organizations and enterprises must operate? What are the advantages and disadvantages of learning to work in a "knowledge environment economy" for businesses and organizations? A working paper by the (OECD, 2008) conducted a survey and asserted that SMEs tend to be under-represented in the international economy in comparison to their significance to national and local economies, even though they constitute the main source of growth in the economy. The studies looked into how SMEs and policymakers view the hurdles to their entry into foreign markets. The conference's outcome paved the way for the creation of the Athens Action Plan for Eliminating Obstacles to SME Access to International Markets. KM principles, as well as the consequences on perceptions of organizational performance. Our interest in researching into this phenomenon came up as a result of currently insufficient empirical literature and insight on regressed and estimated coefficients of probable factors which may restrain or refrain the knowledge management implementation process under the current changing economic trend.

Research Objectives and Hypotheses

The main objective is to investigate and ascertain the influence of staff recruitment quality, employee's behavior to change management, inadvertent tacit knowledge, and knowledge update programs (investigated variables) on the Knowledge management implementation process in selected companies in Ghana. This will help unveiled some positive and negative elements which may either propel or impede the company's KM implementation processes. In other to add up to the literature, the following hypotheses were tested and established their significance on KM implementation processes in businesses.

$\mathrm{H} 1$.Staff recruitment quality affects the KM implementation process (statistically significant at $p(.000)<0.05)$

$\mathrm{H} 2$. Employees behavior to change management affects the $\mathrm{KM}$ implementation process (statistically not significant at $p(0.553)>0.05)$

H3. Tacit knowledge affects KM implementation process $(p(0.770)>0.05)$

$\mathrm{H} 4$. Knowledge update programs affect the KM implementation process (statistically significant at $\mathrm{p}(.000)<0.05)$ 


\section{Theoretical Foundations and Literature Review}

Knowledge use influences economic growth (Romer, 1990). Following this, (Drucker, 1993) offered a historical perspective on how economic developments could be interpreted in the context of business. Managing staff competencies, as well as linking corporate knowledge assets that are both implicit and explicit, are important aspects of this. A renowned United Kingdom management consultancy firm and developers of competency management, define managerial competency as a fundamental feature of a person that allows them to deliver superior performance in a specific job, role, or environment, according to (Singh \& Yadav, 2009). Professional competencies, on the other hand, depend significantly on strategic knowledge management as a skill that encompasses knowledge generation, knowledge organization and preservation, transfer of knowledge, and information applications, all of which help a company establish and sustain a competitive edge (Davenport \& Prusak, 1998; Ferreira, Mueller, \& Papa, 2018; Heisig et al., 2016). These resources and capabilities, according to a knowledge-based perspective of the organization, are knowledge-related and knowledge-intensive resources and skills (Grant, 1997). Several concerns have been expressed about the resources that can be employed to generate, collect, and assimilate knowledge-intensive processes. What are the best ways to develop, remodel, and adapt experience and understanding procedures to changing technology and market conditions? What resources and expertise are available for KM process design? But, more significantly, we want to figure out what reasons are preventing or complicating the KM approach.

To have a thorough understanding of the impediments to knowledge management processes and firms' long-term viability. The Game Theory (Chatterjee \& Samuelson, 2001) served as a significant operation research technique that lays a framework for finding the specific strategy that will result in a maximum gain or minimum loss under defined parameters. As a result, game theory can be characterized as a body of knowledge that interacts with the decision-making of two or more competent individuals in a conflict and competition situation. The application of this theory in business and economics will aid companies in creating an optimum strategy to succeed in every competitive situation of uncertainty and incomplete knowledge. Interestingly, organizations' or firms' actual decision making and the other process of action or implementation requires specific knowledge for its application. Herbert Simon says that decision-making is very important for an organization. Decisions need to be taken properly and on time to avoid the objective of the organization going in vain (Simon, 1979). The study was guided by the above concept as a framework-specific philosophy. The goal of the research is to better understand the interactions between knowledge management implementation and its enablers and impediments to the long-term viability of companies.

\section{The Concept of KM}

Knowledge management (KM) is concerned with the acquisition, creation, storage, sharing, transferring, and use of implicit and explicit knowledge to achieve product and process innovation, performance improvement, and long-term competitiveness (Madhoushi et al., 2010; Nonaka \& Takeuchi, 1995). Knowledge management is a topic that has only been around for about 25 years. According to (Koenig, 2012), in its early stages, knowledge management was all about holistically organizing information and knowledge. A description of knowledge management has been given by (Davenport \& Prusak, 1998) as a process of capturing, disseminating, and successfully utilizing knowledge" in the early days of the field. Knowledge management is still widely used by academics and practitioners today. Knowledge 
management, according to the article, is a discipline that promotes an integrated means to locate, store, assesses, extract, and transfer all of a company's information. Records, bookkeeping, principles, practices, and previously undocumented talents and expertise in individual employees are examples (Duhon, 1998). Knowledge management, according to the definition above, is the process of a company's knowledge being managed. Several types of organizational knowledge have been found thus far, the two primary categories being explicit and implicit knowledge. Explicit knowledge is the knowledge that has been written down in the form of materials that can be reused, whereas implicit knowledge is the knowledge that has been learned as a consequence of job experience (Sukumaran et al., 2018). As a result, businesses require both explicit and implicit information, as well as a method for effectively managing both. Long time spans to adjust operations to suit policy, resistance to change, low or no exploitation of some research findings by the Board, incorrect media transmission of information, and bureaucracy in some processes are all challenges of knowledge management. Tacit knowledge can be disseminated inadvertently. The application of knowledge may fall short of the organization's expectations.

The Relevance of KM implementation in Firms

According to (Singh \& Yadav, 2009), effective Knowledge management is an engine for economic growth. Knowledge expands as more freedom is given to it to flow. The service industry accounts for $60 \%$ of India's GDP, and expertise is essential for individuals working in it. Knowledge and information are used interchangeably in knowledge management. Both of these ideas are at the basis of effective workplace human resource development. Both learning and performance models of human resource development are heavily supported by knowledge management. Knowledge management, on the other hand, is one of the essential components of quality management. The issue is that knowledge management and quality management are thought to be unrelated fields, and their connection has yet to be extensively studied. Comprehending these two critical organizational processes will help practitioners create and implement appropriate programs and services that make full use of both processes. Knowledge management as a critical component of the quality management process can aid in the generation and usage of knowledge within the company. Research conducted by (Ujwary-Gil, 2011) highlighted no how to develop and attain a competitive advantage in the market, there is a need for cooperation and knowledge sharing throughout the organization's communities. In this research, cooperation is not always the case, so it's worth thinking about why that is. Again, a descriptive analysis was carried out by (Ahmad, 2011) to enhance the created KM model by evaluating current KM initiatives, activities, and tools, as well as environmental aspects and activities that may be crucial to the effective implementation and deployment of $\mathrm{KM}$ in the construction sector. The lack of structured procedures for building and using knowledge management systems is a barrier to KM deployment in construction enterprises. In addition, issues that may stymie or impede the successful implementation of KM procedures and tools were described and evaluated. The ability of the organization to absorb external knowledge - absorptive capacity - is a critical part of the knowledge production and innovation process. The concept of absorptive capacity has developed as a common thread in the literature on vibrant knowledge and practical learning (Teece, Pisano, \& Shuen, 1997). The term absorptive capacity was coined by (Cohen \& Levinthal, 1989) to understand the concept's multidimensional nature, he defined it as the firm's ability to recognize, adapt, and exploit knowledge from the environment (Zahra \& George, 2002). Absorptive capacity can be seen as a set of dynamic capabilities that allow firms to absorb, integrate, convert, and utilize external data, and it is thus a prerequisite for 
implementing innovation processes. Absorptive capability may improve an organization's ability to support information sharing procedures, resulting in improved performance outcomes (Patterson \& Ambrosini, 2015) as well as a competitive advantage. The integration of technology and intellectual resources is critical for organizational longevity in strategic knowledge management (Heisig et al., 2016). The contrast between the previous and present knowledge networking underpins such relationship.

Besides, research conducted by (Sukumaran et al., 2018) have reported on some challenging factors of KM implementation such as keeping up with the changing environment or resistance to change management, lack of encouragement through restricted or no use of some research findings, staff quality, public use of information, unintended transfer of tacit information, and failure to pursue all knowledge update programs are among those that are organization-specific. According to (Gurteen, 2007) identified a handful of these difficulties (particularly the first two) as impediments to information sharing. Also mentioned bureaucracy as a common organizational barrier, which is a more localized issue for government agencies and departmental activities. The primary sources of these challenges could be from organizational and learning hurdles (Alosaimi, Renukappa, \& Suresh, 2017) recognized as impediments to knowledge management. But the major factor could be huge bureaucracies stemming from government institutions to obstruct in a variety of ways. This usually requires managerial input or effort from all employees to overcome the situation.

Research conducted by (Sukumaran et al., 2018) emphasized the necessity to keep up with the changing environment was mentioned as another problem. This finding points to an issue with identifying the need for change, change management, or the ability to innovate. It was further positioned that conservatism is an issue in change management, implying that change management is an issue for most firms. As a result, to effectively embrace KM, the organization will most likely need to improve its ability to manage change. Staff recruiting was noted as a barrier to KM implementation. In the KM process, it does have an impact on knowledge generation, which may be tied to the prior topic about keeping up with the varying business environment. The availability of qualified employees is seen as a unique barrier to $\mathrm{KM}$, it is a problem that needs to be handled by those in charge. The main concern identified by the respondents was the unintentional sharing of tacit knowledge. According to (Petersen \& Poulfelt, 2002) among others, point to knowledge utilization is an integral aspect of the KM process. Through their knowledge update workshops, the business tackled the issues of training and updating the expertise of its employees. This is in line with (Ishrat \& Rahman, 2019; Kim \& Lee, 2012), who stated that the human aspect in an organization can contribute to knowledge sharing for the organization's growth and improvement. This is a concern for the firms' operations, as many knowledge updates and training events scheduled for the past year did not take place. The context of KM is figuring out how to innovate in the face of the limits to create a positive learning experience.

\section{Methodology}

The technical route of this research was an exploratory study that employed a survey design. This enabled the researcher to use questions in soliciting responses from people who had indepth knowledge regarding the subject matter. The study design was suitable for accomplishing the survey aims and addressing the inquiry questions (Cooper, Schindler, \& Sun, 2006). This is a qualitative research method used to acquire a better understanding of the issues associated with knowledge management implementation. Data were purposively collected from managers, supervisors, and secretaries of companies regarding their 
perspectives on the KM implementation. The information collected was subjected to thematic investigation.

Modelling, Methodological Framework, and Data Analysis

This paper assessed the new experiential impacts linked to the application of knowledge management in businesses in Ghana. In the Multiple Linear Regression (MLR) model, the analysis followed a well-established pattern. Following the estimation of descriptive statistics for five (5) variables. The following is the general form of our empirical multiple regression model:

$$
K M=\alpha_{\theta}+\beta S R Q+\beta R C M+\beta \Pi K+\beta K U P+\varepsilon
$$

Where;

SRQ=Staff Recruitment Quality

$\alpha=$ Trend/Constant

$\beta=$ Coefficients

$\mathrm{RCM}=$ Resistance to Change Management

ITK=Inadvertent Tacit Knowledge

KUP=Knowledge Update Programs

$\mathrm{KMI}=$ Knowledge Management Implementation

$\varepsilon=$ Error of term

\section{Discussion of the Result of the Study \\ Descriptive Statistics of Respondents}

The results are shown in table (1) specifies the descriptive statistics of our respondents. The data for this research was gathered from ten business locations in Ghana; namely Accra, Ho, Koforidua, Sunyani, Takoradi, Cape Coast, Kumasi, Tamale, Wa, and Bolgatanga.

From the data obtained, most of our respondents were males, which account for $62 \%$ whereas $38 \%$ were females. This is an indication that most men are actively involved in doing business in Ghana. Again, 16 percent of our respondents were between the ages of 31 and 40, 48 percent were between the ages of 41 and 50, 9 percent were between the ages of 20 and 30, 22 percent were between the ages of 51 and 60 , and 5 percent were over 60 . This shows that a higher percentage of 48 of our respondents were within the working population as posit by the (ILO, 2010) were duly considered as part of the research. Hence, valid data were gathered from the respondents to form the basis and justification for the research. 9\% of our respondents have a Ph.D., followed by a master's degree accounting for $48 \%$ and $43 \%$ representing respondents with Bachelor's degrees. This is also an indication that a higher percentage of the respondents have graduated from tertiary institutions and are involved in businesses. The findings from the descriptive statistics show that a higher percentage of our respondents are married which accounted for $61 \%, 17 \%$ are single, whereas $14 \%$ and $8 \%$ are divorced and widowed respectively. This is an indication that the married category has to work hard to gain income to cater to their families. The responses were gathered from different companies such as; $18 \%$ of the respondent are from Accra Brewery Company whilst $5 \%$ are from Processing Company Cocoa. 12\% accounted for Kumasi Brewery Company, 11\% been Ghana Post, 13\% been SIC Insurance Company, 12\% been Vodafone Ghana, 15\% from MTN Ghana, Airtel-Tigo Ghana $11 \%$ and 3\% from Coca Cola Company and Unilever Ghana respectively.

More importantly, the field survey shows that a higher percentage of 67 of our responses were gathered from top managerial positions whereas $27 \%$ and $6 \%$ play supervisory and 
clerical roles. This is an indication that required information was gathered from the right sources to justify the credibility of the research findings.

Table 2 gives a reflection on the statistical description of the variables, the results show that the variables are not wider apart from themselves. The same samples were arrived at. In terms of values, the minimum values, maximum values, mean values, and standard deviations are practically identical. This means that the variable is not wider dispersed from the mean. The variables generally show low standard deviation values.

Table 3 shows the extent to which the data for the study can reproduce similar results when a similar methodological approach is applied. Hence in research, a reliability test indicates that the data used must regenerate or repeat the same results when a similar approach is used. For example, a scale or test is said to be trustworthy if its measurement yields the same result when repeated under the same conditions (Golafshani, 2003). Testing for dependability is important since it pertains to the consistency of a measuring instrument's parts (Golafshani, 2003). As a result, Cronbach's Alpha was utilized as a measure of internal consistency and reliability. Cronbach's Alpha is a reliability coefficient that shows how well elements in a data collection are positively associated. Cronbach's alpha tests were used to determine the reliability of the multiple-question Likert scale questionnaires. More importantly, Cronbach Alpha measures the inter-correlation among internal consistency and reliability of the test items were greater with a score of one (1). But mostly the acceptable measurement is set to fall within 0.7 to 0.9 (Landau \& Everitt, 2003). However, our outcome of the test result in table 2 shows that the estimated Cronbach Alpha for all scale of measurement variables is justified within the measurement of constructs of 0.7 to 0.9 which simply implies a high correlation between the items and the questions set for the survey. The value is an indication that our questionnaire used for the study has satisfied the reliability test.

Validity test

Validity in research establishes whether a study accurately measures what it was designed to measure and the accuracy of the investigation's findings. According to (Golafshani, 2003), construct validity is a term used in research to describe the validity of a study. The construct is the original thought, query, or hypothesis that guides which data should be collected and how it should be collected. The supervisor double-checked all of the questions. The goal is to ensure that the instrument is adequate and representative of all of the variables being measured. Before the final administration of the data instrument to collect data for the research, we pre-tested its validity and reliability. A pilot test was conducted using forty-five (45) respondents from the companies to determine the accuracy and validity of the instruments before gathering final data for the study. This aided us to modify the research instrument making it clear to understand and eliminate the uncertainty of items before the final distribution.

Table 4 divulges the matrix of correlation of the estimated variables of concern. Although most of the construct items significantly correlated among themselves, KMI strongly correlated with SRQ $\left(.924^{* *}\right)$ at a $1 \%$ significant level. We, therefore, accepted that there is a strong relationship between $\mathrm{KMI}$ and SRQ. Hence, staff recruitment quality is a fundamental element of consideration for knowledge management implementation in every company. Again, the matrix shows that KMI correlated with KUP $\left(.691^{* *}\right)$ at a $1 \%$ significant level. This indicates that SRQ and KUP have a high impact on KMI. These are major elements of consideration in KM implementation. All construct items established a statistically significant relationship amongst themselves but SRQ and KUP have correlated strongly with KMI.

Regression Analysis 


\section{Durbin Watson Statistic Test}

The sample adequacy was determined using the Durbin Watson statistic test for variable model analysis. In the residuals of statistical regression analysis, we looked for autocorrelation. The value of the Durbin-Watson statistic will always be between 0 and 4 . However, a value of 2.000 was obtained in this example, showing a positive autocorrelation. According to table 5, the R-value of.939 indicates a high level of prediction. The $R$ square value of.882 indicates that our independent variable explains 88.2 percent of the variability in our dependent variable (Knowledge Management Implementation). As a result, factors other than the predictors included in this model account for 12 percent (100 percent - 88 percent) of the variation. The adjusted $R$ square value of 0.880 shows that the independent factors explain 88.0 percent of the variation in the outcome variable.

The analysis of variance was tested using two or more factors to compare the variables in table 6 . The total regression model was checked for a fair fit for the data using the F-ratio in the ANOVA (Table 6). From the table, the series of residual point values of difference is 290 whereas the series of residual point's sum of squares value is 192.6878 . The independent variable is statistically significant in predicting the dependent variables, as evidenced by this, $F(4,290)=542.394, p(.000)<.05$ (the regression model fits the data well.).

Table 7 illustrates the statistical significance of the dependent variable on the independent variable. SRQ and KUP are statistically significant, according to the test results at $p(.000)$ $<0.05$. This indicates that KMI is positively influenced by SRQ and KUP. However, RCM and ITK are statistically not significant at $p(0.553)>0.05$, and $p(0.770)>0.05$ respectively. This indicates that KMI is negatively influenced by RCM and ITK. The collinearity with variance inflation values, on the other hand, is all less than 10, indicating that there is no multicollinearity diagnostic in the data set.

The predicted variables on the dependent variable in Table 8 have a standard residual value of 3.686 , indicating that the data set is not normally distributed. The usual residual value exceeds -3 to 3 when plotted. In this example, however, Cook's distance, which has the highest value (0.156) of all predictor variables, shows that it has an impact on the dependent variable (KMI).

\section{Discussion of Result}

Before the study, four (4) objectives were established to navigate into the relationship amidst staff recruitment quality, resistance to change management, inadvertent tacit knowledge and knowledge update programs, and Knowledge management implementation in the Ghanaian context for SMEs.

To better understand the importance and mutual relationship that exist between these variables, ten Ghanaian companies were purposively selected to investigate and ascertain the influence of staff recruitment quality, resistance to change management, inadvertent tacit knowledge, and knowledge update programs on the Knowledge management implementation process in Ghana and how important to factor them into our business management strategy. This will enhance and sustain a competitive advantage, and developing further innovative business strategies in the knowledge management implementation process.

Our finding gave us signification result, which lay bare to prior literature. This study revealed the obstacles to knowledge management implementation in most companies and 
this can be describe as a difficult for most companies to accept change.Again the result of this research is an important contribution to the existing knowledge on KM implementation. The results disclose that hypotheses one (1) and four (4) have direct effects on the KM implementation process owing to their statistically significant values. The result is an indication that the quality of staff recruited and the knowledge update programs received by employees are factors of consideration for a successful knowledge management implementation in companies. Secondly, hypotheses two (2) and three (3) were not statistically significant. This is also an indication that the employee's resistance to change management, as well as inadvertent knowledge, are impediments to successful knowledge management implementation in companies.

Generally, our findings bring to bear that companies in Ghana have high regard for knowledge management due to its positive effect on enhancing and sustaining a competitive advantage, and development of innovative business strategy out of it. Companies must see staff recruitment quality, resistance to change management, inadvertent tacit knowledge, and knowledge update programs as considerable indicators for a successful KMI. The application of these research findings could be used as factors of consideration for KM appraisal and organizational management process, and enhancing competitive advantage, company performance, and survival.

In this research, we accepted hypotheses one (1) and four (4) due to their positive impact on KMI. Nonetheless, we reject hypotheses two (2) and three (3) because, in the process of $\mathrm{KMI}$, employees' resistance to change management and their inadvertent knowledge are challenges to the successful KM implementation process. We, therefore, conclude that resistance to organizational change management and individual's tacit knowledge is a hindrance to knowledge management implementation in every organizational setting. Hence, KM implementation is not $100 \%$ assured due to the negativities established by these two construct items and their effects on KM implementation. Despite the difficulties that knowledge management poses, particularly in firms, its importance cannot be overstated. It is also obvious that, through its employees, knowledge management has a significant impact on organizational performance. The successful result of their endeavor to apply their knowledge will enable the companies to not only save costs but also expand market shares through client retention and achieve a competitive advantage.

Hence, having a pre-requisite knowledge on staff recruitment quality, employee's behavior to change management, inadvertent tacit knowledge, and knowledge update programs and their application will determine the success of KM implementation. A firm's (specific) asset positions (such as a portfolio of difficult-to-trade knowledge assets and complementary assets) and evolution path(s) contribute to its competitive advantage, as noted in (Teece et al., 1997). However, we believe that firms' ability to strategize effectively and maintain competitive advantage depends on the effectiveness and success of knowledge management processes when all barriers to strategic management processes are removed.

However, the positivity of the statistical variables will ensure the success of the KM implementation process in every company and its competitiveness in the same business environment.

\section{Managerial Implications}

Ensuring successful knowledge implementation among companies or organizations will enhancing and sustaining a competitive advantage, and development of innovative business strategies. It will also help in identifying some factors of consideration for business appraisal 
and placing organizations or companies at a competitive advantage. Knowing staff recruitment quality, employees resistance to change management, inadvertent tacit knowledge of employees, and knowledge update programs for employees will position organizations or firms as to when, where, and how to channel their available resources to further take advantage of the ever-changing business atmosphere to meet the needs of its market and maximize profit.

In a broader sense, the game theory intended to identify and explain the strategic behavior of game participants who are aware that actions made in the competition have an impact on all game participants, whether good or harmful. The good which comprises staff recruitment quality, and knowledge update programs were accepted whereas the bad such as resistance to change management, and inadvertent tacit knowledge is not supported due to their negative impact on the $\mathrm{KM}$ implementation process and hence impeding organizational competitiveness.

\section{Conclusion, Limitations and Future Research}

Even though our variables or construct items of analysis had some shortcomings, such as the possibility of some research questions not been answered due to COVID-19 which poses restrictions to collect data from some areas, time limitation, and financial constraints to meet transportation cost of data collection. However, the researcher tried everything possible to engage respondents to offer their best in eliciting responses for the study. The research established strong policy support for organizational knowledge management implementation as a prerequisite and requirement for enhancing and sustaining the competitive advantage of businesses and further develop an innovative business strategy from the construct variables which have statistical relevance on the dependent variable (KMI). However, more crucially, an additional study can be carried out in other locations of Ghana by combining other variables such as extensive bureaucracies, and non-utilization of research reports, which were not included in our hypotheses, can be tested to ascertain its significance on the KM implementation process.

\section{Innovation of the Paper}

The study aimed at supporting and resonating that staff recruitment quality and knowledge update programs determine how successful KM implementation will be whereas resistance to change management, and inadvertent tacit knowledge factors to unsuccessful KM implementation and hence impeding organizational competitiveness. This paper, therefore, brings to bear that there are refraining and restraining forces in KM implementation. In order words, there are propelling and impeding factors to be considered in knowledge management implementation to further positioned the organization at a competitive advantage over others within the same business environment. This will help maximize productivity and reduce the failure of most businesses as a result of other negative construct variables expressed in this research. Hence, the adoption and application of this concept will help in a successful KM implementation in every organizational setting. At present, no such specific work has been done in Ghana to the extent of developing a graphical abstract or framework. This then propels our interest in this area of research to investigate and develop such a concept as practical factors of consideration for a successful knowledge implementation that will subsequently lead to successful business management and competitive advantage. Hence, an area that needs attention for policy formation by focusing on its impact on organizational success. 


\section{Declaration of Competing Interest}

The authors declares no competing interests in the publication of this work.

\section{References}

Ahmad, H. S. M. (2011). Development of KM model for knowledge management implementation and application in construction projects. University of Birmingham,

Alosaimi, H., Renukappa, S., \& Suresh, S. (2017). The Key Challenges for Managing Knowledge in the Kingdom of Saudi Arabia Construction Industry: An Empirical Study. 631.

Chatterjee, K., \& Samuelson, W. (2001). Game theory and business applications: Springer.

Cohen, W. M., \& Levinthal, D. A. (1989). Innovation and learning: the two faces of R \& D. Economic journal, 99(397), 569-596.

Cooper, D. R., Schindler, P. S., \& Sun, J. (2006). Business research methods (Vol. 9): Mcgrawhill New York.

Davenport, T. H., \& Prusak, L. (1998). Working knowledge, harvard business school press.

Drucker, P. F. (1993). The rise of the knowledge society. 17(2), 52-72.

Duhon, B. (1998). It's all in our heads. 12(8), 8-13.

Ferreira, J., Mueller, J., \& Papa, A. (2018). Strategic knowledge management: theory, practice and future challenges. Journal of Knowledge Management, 24(2), 121-126. doi:10.1108/jkm-07-2018-0461

Golafshani, N. (2003). Understanding reliability and validity in qualitative research. 8(4), 597607.

Grant, R. M. (1997). The knowledge-based view of the firm: implications for management practice. 30(3), 450-454.

Gurteen, D. (2007). KM2. 0: KM goes Social. Paper presented at the Online Information.

Heisig, P., Suraj, O. A., Kianto, A., Kemboi, C., Arrau, G. P., \& Easa, N. F. (2016). Knowledge management and business performance: global experts' views on future research needs. Journal of Knowledge Management.

Ishrat, R., \& Rahman, W. (2019). Factors of knowledge sharing: a literature review. 5(2), 219254.

Kim, T., \& Lee, G. (2012). A modified and extended Triandis model for the enablers-processoutcomes relationship in hotel employees' knowledge sharing. The service industries journal, 32(13), 2059-2090.

Koenig, M. (2012). What is KM? Knowledge management explained. 4.

Landau, S., \& Everitt, B. S. (2003). A handbook of statistical analyses using SPSS: Chapman and Hall/CRC.

Madhoushi, M., Sadati, A., Delavari, H., Mehdivand, M., \& Hedayatifard, M. (2010). Facilitating knowledge management strategies through IT and HRM. 9(10), 57.

Nonaka, I., \& Takeuchi, H. (1995). The knowledge-creating company: How Japanese companies create the dynamics of innovation: Oxford university press.

OECD. (2005). Oslo manual: Guidelines for collecting and interpreting innovation data: Org. for Economic Cooperation \& Development.

OECD. (2008). Removing Barriers to SME Access to International Markets.

Patterson, W., \& Ambrosini, V. (2015). Configuring absorptive capacity as a key process for research intensive firms. 36, 77-89.

Petersen, N. J., \& Poulfelt, F. (2002). Knowledge management in action. 2(33), 1-23.

Romer, P. (1990). Endogenous Technological Change. Journal of political Economy, 98, S71 S102. 
Simon, H. A. (1979). Rational decision making in business organizations. American economic review, 69(4), 493-513.

Singh, J., \& Yadav, P. (2009). Challenges and strategies to knowledge management: Case studies of selected companies. 1(1), 38.

Sukumaran, S., Amalathas, S., Simon, C. G. K., Mustapha, S. S., Hashem, I. A. T., \& Zulkifli, A. (2018). A Case Study on Knowledge Management Implementation in the Banking Sector Issues and Challenges. 1-6.

Teece, D. J., Pisano, G., \& Shuen, A. (1997). Dynamic capabilities and strategic management. Strategic management journal, 18(7), 509-533.

Ujwary-Gil, A. (2011). The analysis of barriers to knowledge management. 20, 84.

Zahra, S. A., \& George, G. (2002). Absorptive capacity: A review, reconceptualization, and extension. Academy of management review, 27(2), 185-203. 
INTERNATIONAL JOURNAL OF ACADEMIC RESEARCH IN BUSINESS AND SOCIAL SCIENCES Vol. 11, No. 12, 2021, E-ISSN: 2222-6990 @ 2021 HRMARS

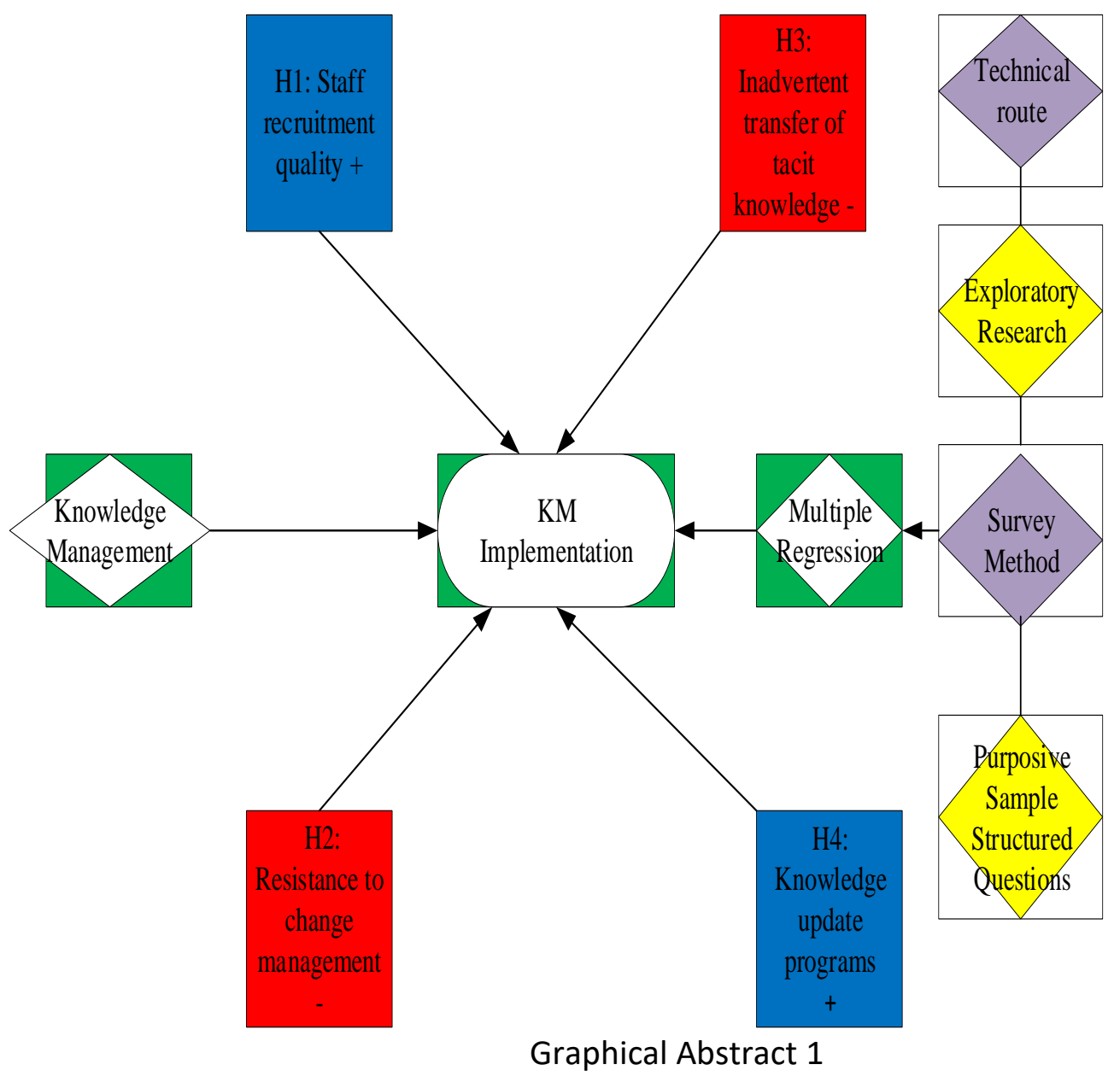

Table 1: Descriptive Statistics for the Sample. N= 295 Variables 


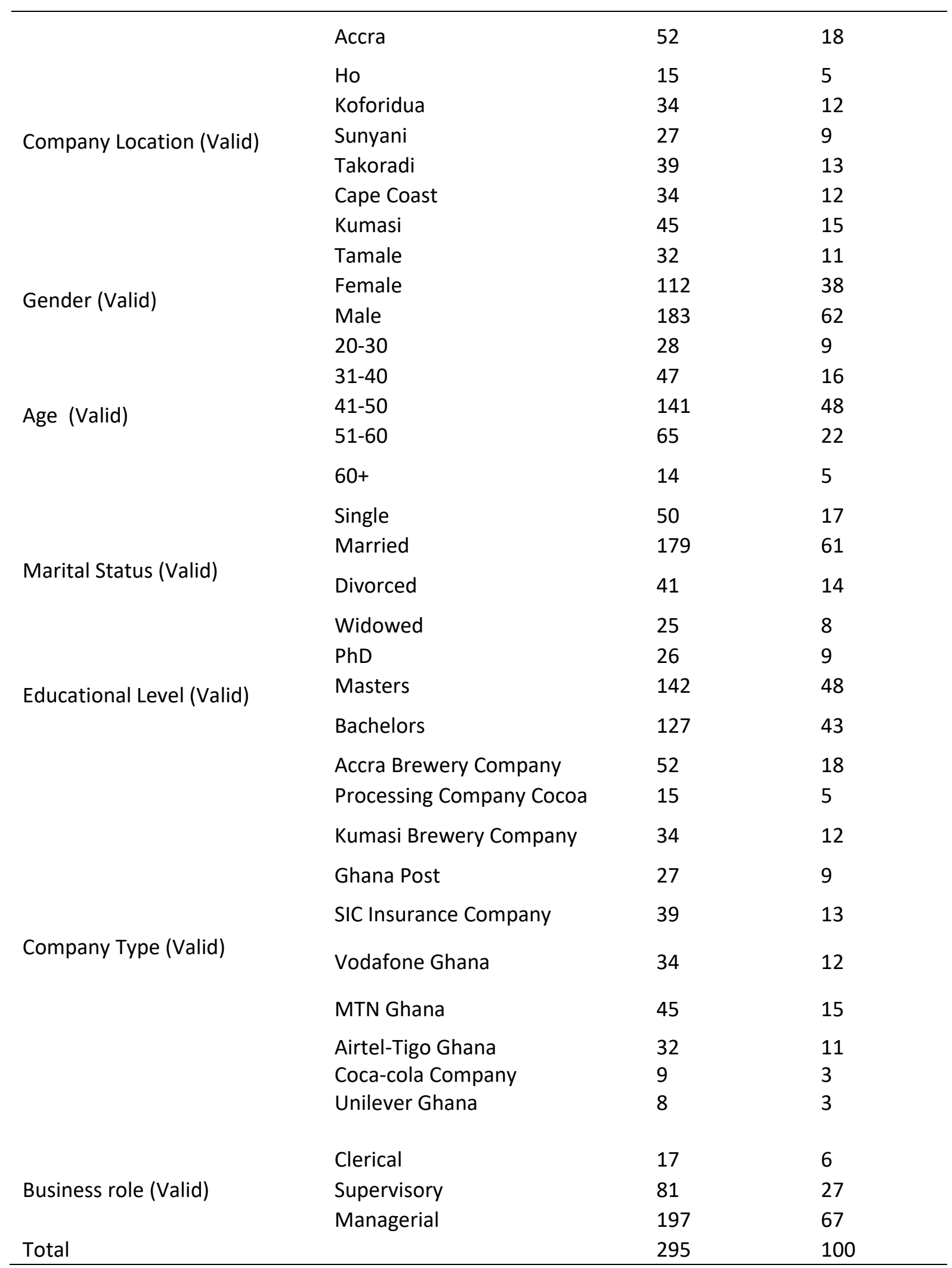

Field survey, (2021)

Table 2: Statistical Description of all Variables applied in the Data Analysis

\begin{tabular}{llllll}
\hline Construct Items & $\mathrm{N}$ & Minimum & Maximum & Mean & Std. Deviation \\
\hline SQR & 295 & 1 & 5 & 4.119 & 0.856 \\
\hline
\end{tabular}


INTERNATIONAL JOURNAL OF ACADEMIC RESEARCH IN BUSINESS AND SOCIAL SCIENCES Vol. 11, No. 12, 2021, E-ISSN: 2222-6990 @ 2021 HRMARS

\begin{tabular}{llllll}
\hline RCM & 295 & 1 & 5 & 4.076 & 0.816 \\
ITK & 295 & 1 & 5 & 4.120 & 0.861 \\
KUP & 295 & 1 & 5 & 4.150 & 0.744 \\
KMI & 295 & 1 & 5 & 4.121 & 0.810 \\
Valid N (listwise) & 295 & & & & \\
\hline
\end{tabular}

Field Survey, 2021

Table 3: Test for Reliability

\begin{tabular}{llll}
\hline variables & Cronbach's Alpha & & N of Items \\
\hline SRQ & 0.853288 & 5 & \\
RCM & 0.841236 & 3 & \\
ITK & 0.837035 & 3 & \\
KUP & 0.937823 & 3 & \\
KMI & 0.829004 & 3 & \\
\hline
\end{tabular}

Field Survey, 2021

Table 4: Pearson's Correlation Coefficient: Correlation matrix

\begin{tabular}{lllllll}
\hline Variables & Model & SRQ & RCM & ITK & KUP & KMI \\
\hline SRQ & Pearson Correlation & 1 & & & & \\
& Sig. (2-tailed) & & & & \\
\multirow{4}{*}{ RCM } & N & 295 & & & \\
& Pearson Correlation & $.593^{* *}$ & 1 & & \\
& Sig. (2-tailed) & 0 & & & \\
ITK & N & 295 & 295 & & & \\
& Pearson Correlation & $.402^{* *}$ & $.363^{* *}$ & 1 & & \\
& Sig. (2-tailed) & 0 & 0 & & & \\
KUP & N & 295 & 295 & 295 & & \\
& Pearson Correlation & $.601^{* *}$ & $.601^{* *}$ & $.275^{* *}$ & 1 & \\
& Sig. (2-tailed) & 0 & 0 & 0 & & \\
KMI & N & 295 & 295 & 295 & 295 & \\
& Pearson Correlation & $.924^{* *}$ & $.591^{* *}$ & $.382^{* *}$ & $.691^{* *}$ & 1 \\
& Sig. (2-tailed) & 0 & 0 & 0 & 0 & \\
& N & 295 & 295 & 295 & 295 & 295 \\
\hline
\end{tabular}

Note $^{* *}$. Correlation is significant at the 0.01 level (2-tailed).

Table 5: Model Summary

\begin{tabular}{lllll}
\hline $\mathrm{R}$ & $\mathrm{R}$ Square & Adjusted R Square & Std. Error of the Estimate & Durbin-Watson \\
\hline $.939 \mathrm{a}$ & 0.882 & 0.880 & 0.280 & 2.000 \\
\hline
\end{tabular}

Predictors: (Constant), KUP, ITK, RCM, SRQ

b. Dependent Variable: KMI

Table 6: ANOVA Test.

\begin{tabular}{llllll} 
& Sum of Squares & df & Mean Square & $F$ & Sig. \\
\hline Regression & 169.969 & 4 & 42.492 & $542.394^{*}$ & $.000 \mathrm{~b}$ \\
\hline
\end{tabular}




\begin{tabular}{llll}
\hline Residual & 22.719 & 290 & 0.078 \\
Total & 192.688 & 294 & \\
\hline
\end{tabular}

Dependent Variable: KMI

bPredictors: (Constant), KUP, ITK, RCM, SRQ

Table 7 Standardized Coefficients values (Multiple Regression)

\begin{tabular}{|c|c|c|c|c|c|c|c|c|c|c|}
\hline & \multicolumn{2}{|c|}{$\begin{array}{l}\text { Unstandardized } \\
\text { Coefficients }\end{array}$} & \multirow{2}{*}{$\begin{array}{l}\begin{array}{l}\text { Standardized } \\
\text { Coefficients }\end{array} \\
\text { Beta }\end{array}$} & \multirow[t]{2}{*}{$\mathrm{t}$} & \multirow[t]{2}{*}{$\begin{array}{l}\text { Sig } \\
.\end{array}$} & \multicolumn{3}{|c|}{ Correlations } & \multicolumn{2}{|c|}{$\begin{array}{l}\text { Collinearity } \\
\text { Statistics }\end{array}$} \\
\hline & B & $\begin{array}{l}\text { Std. } \\
\text { Error }\end{array}$ & & & & $\begin{array}{l}\text { Zero- } \\
\text { order }\end{array}$ & $\begin{array}{l}\text { Par } \\
\text { tial }\end{array}$ & $\begin{array}{l}\text { Par } \\
\mathrm{t}\end{array}$ & $\begin{array}{l}\text { Toler } \\
\text { ance }\end{array}$ & VIF \\
\hline \multirow{2}{*}{$\begin{array}{l}\text { (Cons } \\
\text { tant) }\end{array}$} & \multirow{2}{*}{0.061} & \multirow{2}{*}{0.110} & & 0.5 & 0.5 & & & & & \\
\hline & & & & 57 & 78 & & & & & \\
\hline \multirow{2}{*}{ SRQ } & \multirow{2}{*}{0.756} & \multirow{2}{*}{0.026} & \multirow{2}{*}{ 0.799* } & 28. & 0.0 & 0.923 & 0.8 & 0.5 & \multirow{2}{*}{0.523} & 1.91 \\
\hline & & & & 665 & 00 & 6 & 60 & 78 & & $2^{*}$ \\
\hline \multirow{2}{*}{$\mathrm{RCM}$} & \multirow{2}{*}{-0.016} & \multirow[b]{2}{*}{0.027} & \multirow[b]{2}{*}{$-0.016^{*}$} & & 0.5 & 0.591 & 0 & - & \multirow{2}{*}{0.540} & 1.85 \\
\hline & & & & $\begin{array}{l}0.5 \\
93\end{array}$ & 53 & 1 & $\begin{array}{l}0.0 \\
35\end{array}$ & $\begin{array}{l}0.0 \\
12\end{array}$ & & $1^{*}$ \\
\hline \multirow{2}{*}{ ITK } & \multirow{2}{*}{0.006} & \multirow{2}{*}{0.021} & \multirow{2}{*}{$0.007^{*}$} & 0.2 & 0.7 & 0.382 & 0.0 & 0.0 & \multirow{2}{*}{0.814} & 1.22 \\
\hline & & & & 92 & 70 & 0 & 17 & 06 & & $8^{*}$ \\
\hline \multirow{2}{*}{ KUP } & \multirow{2}{*}{0.238} & \multirow{2}{*}{0.030} & \multirow{2}{*}{$0.219 *$} & 8.0 & 0.0 & 0.691 & 0.4 & 0.1 & \multirow{2}{*}{0.546} & 1.83 \\
\hline & & & & 14 & 00 & 1 & 26 & 62 & & $0^{*}$ \\
\hline
\end{tabular}

a. Dependent Variable: KMI

Table 8 Residuals Statistics

\begin{tabular}{llllll}
\hline & Minimum & Maximum & Mean & Std. Deviation & $\mathrm{N}$ \\
\hline Predicted Value & 1.051 & 5.044 & 4.121 & 0.760 & 295 \\
Std. Predicted Value & -4.037 & 1.214 & 0.000 & 1.000 & 295 \\
Standard Error of Predicted Value & 0.017 & 0.107 & 0.033 & 0.015 & 295 \\
Adjusted Predicted Value & 1.055 & 5.052 & 4.121 & 0.760 & 295 \\
Residual & -1.813 & 1.032 & 0.000 & 0.278 & 295 \\
Std. Residual & -6.476 & $3.686^{*}$ & 0.000 & 0.993 & 295 \\
Stud. Residual & -6.509 & 3.786 & -0.001 & 1.005 & 295 \\
Deleted Residual & -1.831 & 1.088 & 0.000 & 0.285 & 295 \\
Stud. Deleted Residual & -7.032 & 3.876 & -0.002 & 1.022 & 295 \\
Mahal. Distance & 0.052 & 42.087 & 3.986 & 5.455 & 295 \\
Cook's Distance & 0.000 & $0.156^{*}$ & 0.005 & 0.018 & 295 \\
Centered Leverage Value & 0.000 & 0.143 & 0.014 & 0.019 & 295 \\
\hline Dependent Variable: KMI & & & & &
\end{tabular}

